\title{
Correlation of Stripe Disease of Barley with Soil Physical Parameters
}

\author{
Satish Kumar* and S.S. Karwasra \\ Department of Plant Pathology, CCS Haryana Agricultural University, Hisar-125004, India \\ *Corresponding author
}

A B S T R A C T

\section{Keywords}

Stripe disease, barley, Soil, Moisture, Temperature

Article Info

Accepted: 04 April 2019 Available Online: 10 May 2019

\section{Introduction}

Barley (Hordeum vulgare L.) is an important cereal crop in the world ranking next to maize, wheat and rice. It is one of the earliest domesticated food crops. In India, it is an important rabi season cereal crop in Punjab, Rajasthan, Madhya Pradesh, Haryana, Uttar Pradesh and Bihar. In India, area under this crop is 656.25 thousand ha with a production of 1747.45 thousand tons and an average productivity of $2663 \mathrm{~kg} / \mathrm{ha}$ in 2016-17.

In Haryana, area under this crop is 20 thousand ha with a production of 73 thousand tones and an average productivity of 3650 kg/ha during 2016-17 (Anonymous, 2018).
Barley is hardier than wheat crop and is inherently equipped to adapt itself admirably well under limited inputs and marginal lands. Because of its most versatile agro climatic adaptability even the high yielding varieties of wheat could not replace barley in the wheat bowls of India on rainfed, saline, alkaline soils and dryland etc.

The raw material of barley is utilized for malting and brewing purpose besides food grain and cattle feeds. Barley crop suffers from a number of diseases such as stripe rust, leaf rust, covered smut, loose smut, net blotch, stripe disease and leaf blight etc. which cause significant losses to crop yield. Among these fungal diseases, stripe disease 
(Drechslera graminea (Rabenh.) Shoemaker is an important disease which may cause crop loss upto 70-72 per cent under epiphytotic conditions (Pant and Bisht, 1983). Due to the extensive cultivation of high yielding barley varieties, the problem of stripe disease has assumed a significant importance. The pathogen is seed borne in nature and it survives exclusively as mycelium on pericarp or hull of the seed.

Stripe disease incited by Drechslera graminea (Rabenh.) Shoemaker is very destructive disease of irrigated barley crop. This disease is very serious throughout the world, wherever barley is cultivated. It is also common in North India, particularly in Haryana and Rajasthan states and causes hugs loss in grain yield. The disease has been reported from Europe, U.S.A, South Africa, Chin and Japan.

Diseased plant arise only from infected seeds and they become systematically infected, senescence early and produce a poor yield due to shrivelled seed. There is no spread of infection between plants during the growing season. The fungus produces masses of conidia (anamorph of Drechslera graminea) on leaves of diseased plants. These conidia are carried by the wind to developing seed on the ear of healthy plants with in the crop and in neighbouring crops. Developing barley seed is susceptible to infection from anthesis to soft dough stage (Teviotdale and Hall, 1976). Since, some of the spores germinate and infect the developing seed, there is potential for infection to multiply significantly from one season to next season.

The pathogen has been reported as an obligate parasite, and practically no authentic record have been produced yet that conidia are produced on artificial media. But on the other hand, it has been reported that this pathogen successfully sporulates on the lesions on the foliages and glumes under natural conditions.
In Haryana, the disease was first reported by Tyagi (1974) on variety C-138 and in 1976 Harichand further reported on many commonly grown varieties. Disease plant arises only from infected seeds. After the germination of the seed, the pathogen becomes systemic and the plants senescence early and produce poor yield due to the shriveled grains. There is no secondary spread of infection. Since, these conidia germinate and infect the developing seed, so there is potential for the production of diseased seed, which act as source of infection for the next season. Being a seed borne disease, it is observed where the barley crop is grown throughout the world.

Stripe disease is occurring regularly in different barley growing areas of the state. Due to continuous cultivation of susceptible varieties under favorable conditions, it has emerged as a serious problem. Therefore keeping this view in mind, Correlation of stripe disease of barley with soil physical parameters present study was carried out.

\section{Materials and Methods}

The present investigation entitled, "Influence of stripe disease [Drechslera graminea (Rabenh.) Shoemaker] on physio-biochemical parameters of barley and its management" were carried out during 2007-08 and 2008-09 rabi seasons. The field experiments were conducted at the experimental research area of the Department of Plant Pathology, CCS Haryana Agricultural University, Hisar located at $215.2 \mathrm{M}$ above the mean sea level with a longitude of $75^{\circ} 46^{\prime} \mathrm{E}$ and latitude of $29^{\circ} 10^{\prime} \mathrm{N}$ has a wide range of temperature fluctuation during summer and winter seasons and is characterized as a Semi arid Zone. The minimum and maximum temperature ranges from $0^{\circ} \mathrm{C}$ to $48^{\circ} \mathrm{C}$, respectively. The annual average rainfall is $430 \mathrm{~mm}$. The major part of rainfall is received during monsoon season which occurs from July to September. A few 
millimeters of rainfall can be expected in winter too. During 2007-08 crop season the diseased plants were selected at the experimental research area, Department of Plant Breeding (Wheat and Barley section), CCS Haryana Agricultural University, Hisar in the seed production area of variety $\mathrm{BH}$ 393. The variety was sown in a plot size of $2.0 \times 1.5$ meter with three replications in randomized block design.

At maturity these selected plants were harvested separately, threshed and the seed obtained was used for carrying out further studies. All agronomical and cultural practices were followed as per university's recommendations during the crop season.

In each plot through soil thermometer (morning and evening) soil temperature and soil moisture was measured by taking the soil in a standard box and these boxes were hot dried in oven till the soil become dry and later per cent soil moisture was calculated till complete germination was there. Heat unit $\left(^{0}\right.$ days) were calculated according to Gilmore and Rogers (1958).

After complete heading number of infected plants and infected tillers were counted and after that per cent infected plants and tillers were calculated. The per cent infected plants and tillers were correlated with soil temperature (morning and evening) and soil moisture to see any correlation with disease i.e. (soil physical parameters).

\section{Results and Discussion}

Seeds of susceptible variety - BH-393 when artificially inoculated with the isolated fungus produced typical symptoms of the disease which appeared in the form of yellow spots to brown stripes on the seedlings. The symptoms started from base and extended to tip of the leaf causing necrosis of the infected tissues. Initially, fungal infection symptoms appeared in the form of small yellow spots, later on elongating into yellow brown stripes. These stripes started from the base extended to the tip of leaf causing necrosis of the infected tissue (Plate B). When observed under microscope, the necrotic tissues showed abundant sub hyaline to yellow brown coloured conidia. The conidia were thin walled, 2 to 7 septate and cylindrical in shape.

The disease incidence on plant and tiller basis was correlated with the individual soil physical parameters i.e. morning and evening soil temperature, degree days $\left({ }^{\circ} \mathrm{C}\right.$ heat unit) and soil moisture. Stripe disease was negatively correlated with soil temperatures and degree days $\left({ }^{\circ} \mathrm{C}\right.$ heat). But there was positive correlation with soil moisture (Table 1). The data evident that disease incidence on plant basis was negatively correlated with soil temperature $\left({ }^{\circ} \mathrm{C}\right)$ morning and evening with values of -0.99 and -0.98 . Similarly, on tiller basis, there was also negative correlation with soil temperature $\left({ }^{\circ} \mathrm{C}\right)$ morning and evening with values -0.98 and -0.99 on plant and tiller basis, respectively. Heat unit ( ${ }^{0}$ days) was also correlated with disease incidence on plant and tiller basis (Fig. 1).

Table.1 Correlation of stripe disease of barley with soil physical parameters

\begin{tabular}{|l|c|c|c|c|}
\hline \multirow{2}{*}{} & \multicolumn{2}{|c|}{ Soil temperature $\left(^{\mathbf{0}} \mathbf{C}\right)$} & Heat unit $\left({ }^{\mathbf{0}}\right.$ days) & Soil moisture (\%) \\
\cline { 2 - 3 } & Morning & Evening & & \\
\hline Infected plants & -0.99 & -0.98 & -0.98 & 0.83 \\
\hline Infected tillers & -0.98 & -0.99 & -0.99 & 0.84 \\
\hline
\end{tabular}




\section{Fig.1}

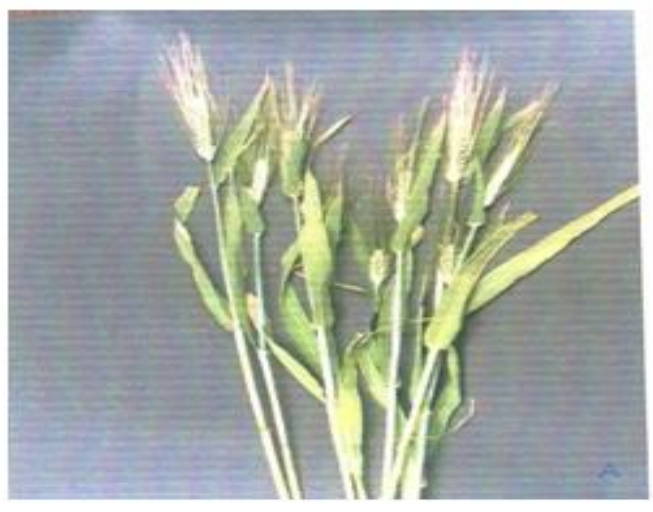

Plate (A) Healthy plant

This was also negatively correlated with disease incidence having values -0.98 and -0.99 . But when soil moisture was correlated with disease incidence on plant and tiller basis there was a positive correlation with disease incidence having value 0.83 and 0.84 . This showed that this is one of the factors which is very important for the stripe disease of barley. This showed that during sowing time if the soil moisture is enough and the seed is infected the disease will certainly be there. Our results are in accordance with the earlier reports of Prasad et al., (1976); Tekauz et al., (1985) and Leukal et al., (1933) who reported that soil temperature below $15^{\circ} \mathrm{C}$ and soil moisture less than $40 \%$ saturation favoured the stripe development in barley.

\section{References}

Annonymus, 2018. Ministry of Agricultural and farmer welfare, Govt. of India.

Gilmore, E.C.Jr. and Rogers, J.S. 1958. Heat unit as a methods of measuring maturity in corn. Agron. J. 50 p.611-615.

Harichand, (1976). Studies on Helminthosporium diseases of barley in

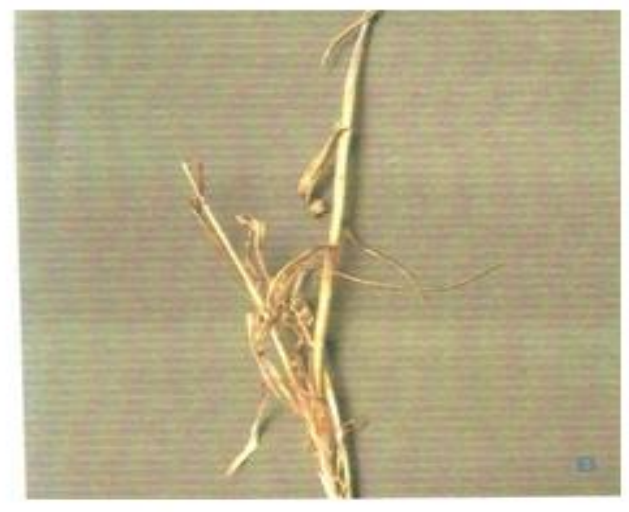

Plate (B) Plant showing typical symptoms of Drechslera graminea

Haryana. M.Sc. Thesis Haryana, Agricultural University, Hisar, India.

Leukel, R.W., Dickson, J.G. and Johnson, A.G.1933. Effects of certain environmental factor on stripe disease of barley and the control of the disease by seed treatment. U.S.D.A. Tech. Bull. 341.39pp.

Prasad, M.N., Leonard, K.J .and Murphy, C.F. 1976. Effects of Temperature and Soil Water Potential on Expression of Barley Stripe incited by Helminthosporium gramineum. Phytopathology 66:631-634.

Tekauz, A., Harper, F.R. and Davidson, J.G.N. 1985. Effect of date of seeding and seed treatment fungicides on infection of barley by Pyrenophora graminea. Can. J. Plant Pathol. 7:408-416.

Teviotdale, B.L., and Hall, K.H. (1976). Effect of light and temperature on number and length of Helminthosporium gramineum conidia produced in culture. Journal of Botany. 45: 644-648.

Tyagi, P.D., (1974). Barley diseases situation in Haryana during 1973-74. All India Barley Workshop, New Delhi.

\section{How to cite this article:}

Satish Kumar and Karwasra, S.S. 2019. Correlation of Stripe Disease of Barley with Soil Physical Parameters. Int.J.Curr.Microbiol.App.Sci. 8(05): 377-380. doi: https://doi.org/10.20546/ijcmas.2019.805.044 